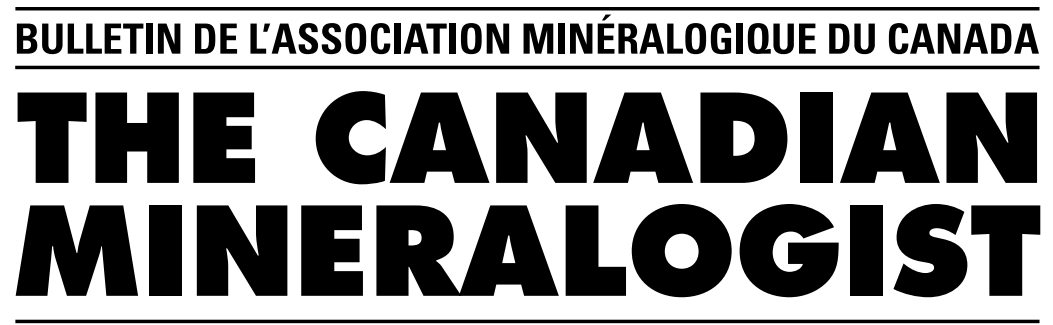

JOURNAL OF THE MINERALOGICAL ASSOCIATION OF CANADA

Volume 39

February 2001

Part 1

The Canadian Mineralogist

Vol. 39, pp. 1-16 (2001)

\title{
SILICA BIOMINERALIZATION OF UNICELLULAR MICROBES UNDER STRONGLY ACIDIC CONDITIONS
}

\author{
RYUJI ASADA ${ }^{\S}$ \\ Graduate School of Natural Science and Technology, Kanazawa University, Kakuma, Kanazawa, 920-1192, Japan \\ KAZUE TAZAKI \\ Department of Earth Sciences, Faculty of Science, Kanazawa University, Kakuma, Kanazawa, 920-1192, Japan
}

\begin{abstract}
Silica biomineralization associated with unicellular microbes (Cyanidium caldarium) living in strongly acidic hot springs were observed by electron microscopy. The unicellular microbes form green biomats undergoing photosynthesis in Kamuiwakka Falls, Hokkaido, Japan. The hot-spring water is strongly acidic, with $\mathrm{pH}$ less than 2, and rich in S. Electron microscopy observations showed that the cell walls of unicellular microbes served as sites for nucleation of silica, polymerization of silicic acid and adhesion of colloidal silica. The precipitates formed an amorphous silica crust on the cell walls, which consist of granular silica spherules with a uniform size. The spherules commonly assimilate the cell walls. Data from X-ray diffraction and electron diffraction of the silica crusts reveal that the crusts are amorphous or of low crystallinity. Electron-dispersion X-ray spectroscopy also showed that the crusts are mainly composed of $\mathrm{Si}$ with traces of $\mathrm{S}$ and $\mathrm{Cl}$. The unicellular microbes have a double-layer cell wall; therefore, silica crusts may form a double layer. FT-IR spectra of cells with and without silica crusts indicated that N-H, $\mathrm{C}=\mathrm{O}$ and $\mathrm{C}-\mathrm{N}-\mathrm{H}$ bands were derived from peptides in cells, whereas the $\mathrm{Si}-\mathrm{O}$ band was derived from silica crusts. Some models also are suggested on the interaction between cell wall and silica under strongly acidic conditions. Processes of silica biomineralization of unicellular microbes as described in this paper have profound implications for evolution of siliciferous microbes.
\end{abstract}

Keywords: amorphous silica, biomineralization, unicellular microbes, acidic condition, green biomats, silicification, silica crust, Cyanidium caldarium, cell wall.

\section{SOMMAIRE}

Une biominéralisation en silice associée à des microbes unicellulaires (Cyanidium caldarium) vivant près de sources thermales fortement acides a été étudiée par microscopie électronique. Les microbes unicellulaires forment des tapis biologiques verdâtres à activité photosynthétique aux chutes Kamuiwakka, Hokkaido, au Japon. L'eau des sources thermales est fortement acide, avec un $\mathrm{pH}$ de moins de 2, et riche en soufre. Nos observations par microscopie électronique montrent que les parois des cellules de ces microbes ont servi de sites de nucléation de la silice, la polymérisation d'acide silicique, et l'adhésion de silice colloïdale. Les précipités forment une croûte de silice amorphe sur les parois des cellules; elle est faite de granules de silice ayant une taille uniforme. Les spherules ont assimilé les parois de façon répandue. Les données de diffraction X et d'électrons révèlent que la croûte de silice est soit amorphe, soit de faible cristallinité. Les spectres de dispersion d'énergie montrent qu'il s'agit de croûtes

§ E-mail address: rasada@kenroku.kanazawa-u.ac.jp 
composées surtout de $\mathrm{Si}$ avec des traces de $\mathrm{S}$ et de $\mathrm{Cl}$. Les microbes unicellulaires possèdent des parois doubles à leurs cellules; c'est ainsi que les encroûtements peuvent aussi être doubles. Les spectres FT-IR des cellules avec ou sans croûtes de silice montrent les bandes $\mathrm{N}-\mathrm{H}, \mathrm{C}=\mathrm{O}$ et $\mathrm{C}-\mathrm{N}-\mathrm{H}$ dérivées à partir des peptides dans les cellules, alors que la bande attribuée à la liaison $\mathrm{Si}-\mathrm{O}$ est dérivée des croûtes de silice. Certains modèles sont discutés à propos de l'interaction des parois cellulaires et de la silice en milieux fortement acides. Les processus de biominéralisation impliquant la silice décrits dans cet article auront des implications importantes pour l'évolution des microbes siliceux.

(Traduit par la Rédaction)

Mots-clés: silice amorphe, biominéralisation, microbes unicellulaires, milieux acides, tapis biologique verdâtre, silicification, croûte siliceuse, Cyanidium caldarium, paroi cellulaire.

\section{INTRODUCTION}

Near the surface of the Earth, hot-spring biomats are a model for geo-ecosystems. Some microbes can live in these hydrothermal environments, and form various biominerals such as $\mathrm{Fe}_{2} \mathrm{O}_{3}, \mathrm{SiO}_{2}$ and $\mathrm{MnO}_{2}$ (Tazaki 1999a). On the other hand, some other types of microbe can enhance or inhibit mineral dissolution in nature by a variety of mechanisms (Ehrlich 1996, Ullman et al. 1996).

Silica biomineralization is a phenomenon caused by microbes such as diatoms and radiolaria that can effectively mediate silica mobilization and fixation. Many fossil records show that diatoms appeared in the late Mesozoic, whereas radiolaria appeared during early Paleozoic time (e.g., Tappan \& Loeblich 1973, Nazarov 1973, 1975, Harper \& Knoll 1975). It must have taken an enormous time for these microbes to acquire abilities to manipulate silica. In order to understand silica control by the microbes, it is important to investigate silicification of unicellular cells. It is also necessary to look for a modern-day aqueous surface-environment where unicellular microbes undergo silicification (Renaut et al. 1998, Asada \& Tazaki 1999). In some examples of hydrothermal systems, such as terrestrial hot-springs and hydrothermal vents on the seafloor, silica precipitation occurs (Tazaki et al. 1996, 1999, Tazaki 1999b, Shikaura et al. 1999, Yamamura et al. 1997). The diversity of species in these extreme ecosystems is restricted. Where $\mathrm{pH}$ is low in the system, the diversity is still more restricted.

Silicified microbial mats (biomats) from modern to Precambrian aqueous settings have been investigated in the past (e.g., Walter et al. 1972, Ferris et al. 1986, Akai et al. 1995, Schultze-Lam et al. 1995, Tazaki et al. 1998, Asada \& Tazaki 1999). Almost all the silica at Loburu Springs, Kenya, nucleated on microbial substrates; nucleation was facilitated by the affinity of silica for functional groups on microbial surfaces (Renaut et al. 1998). These processes of biomineralization contributed to the rapid silicification of the microbes and to their preservation in modern and ancient cherts.

We studied the modes of silica precipitation on cell walls of unicellular microbes in Kamuiwakka Falls, Hokkaido, Japan. Green biomats forming under strongly acidic conditions $(\mathrm{pH}<2)$ consist mainly of the acido- philic and thermophilic unicellular red alga, Cyanidium caldarium, a common member of microflora in acidic hot-springs worldwide (e.g., Hirose 1950, Doemel \& Brock 1971, Ferris et al. 1986, Mann et al. 1992). The presence of $C$. caldarium, characterized by a thin encrustation of silica, has been recognized in strongly acidic hot-springs (Tazaki et al. 1997, 1998, Asada \& Tazaki 1999, 2000). In this paper, we describe silica biomineralization from the viewpoints of macro-scale to micro-scale morphology and chemistry by using electron beam micro-analytical techniques. Some models also are suggested on the basis of interaction between cell walls and silica.

\section{SAMPLeS AND Methods}

\section{Description of the study area}

Kamuiwakka Falls are located on the Kamuiwakka River, in Shiretoko Peninsula, Hokkaido, Japan. Several waterfall pools and spouts of hot springs in which water ranges between $50^{\circ}$ and $80^{\circ} \mathrm{C}$ occur in the study area. The green biomats form only at sites at which flowing water is below $60^{\circ} \mathrm{C}$. Field measurements of the hotspring water shows that its $\mathrm{pH}$ lies between 1.3 and 1.9, the electrode potential versus the standard hydrogen electrode (Eh) is 570 to $630 \mathrm{mV}$, and the electrical conductivity (EC) is 17 to $22 \mathrm{mS} / \mathrm{cm}$ (measured in November 1995, October 1997, October 1998 and June 2000).

Away from the pools, the river depth is mostly less than $30 \mathrm{~cm}$. Green biomats are widely distributed over the face of falls on which flowing water of mixed river and hot-spring provenance ranges between $30^{\circ}$ and $60^{\circ} \mathrm{C}$ (Tazaki \& Ishida 1996, Tazaki et al. 1997, 1998, Asada \& Tazaki 1999). The faces of the falls near the spouts also are biomineralized. The green biomats form coatings less than $1.0 \mathrm{~mm}$ thick on the surfaces of white siliceous substrates that are regarded as white stromatolites, here called white biomats after Asada \& Tazaki (1999).

\section{Green biomats: observations and analyses}

The green biomats were inspected using an optical microscope (Nikon NTF2A), a scanning electron microscope (SEM; JEOL JSM-5200LV) and a transmission 
electron microscope (TEM; JEOL JEM-2000EX). After staining with 4,6-diamidino-2-phenylindole (DAPI), the presence of chlorophyll and a living state were confirmed by autofluorescence and fluorescence when the samples were viewed under an episcopic fluorescence microscope (Nikon EFD3).

The grain mounts of green biomats were handpicked onto a sample holder for SEM examination (scanning electron microscope, SEM; JEOL JSM$5200 \mathrm{LV}$ ). The biomats were sectioned perpendicular to the surface with a cutter knife. After drying in air, the surface was coated with carbon and examined at an accelerating voltage of $15 \mathrm{kV}$.

For TEM examination, a small quantity of green biomats was suspended in distilled water. A drop of the suspension was mounted on a micro grid. The suspension also was treated with ultrasonic waves for three minutes to detach cells from silica crusts before these were mounted on a micro grid. After drying in air, the uncoated sample was observed at an accelerating voltage of $200 \mathrm{kV}$. Furthermore, cells in the primary suspension were concentrated by centrifugation for the preparation of ultra-thin sections. The concentrated cells were included in agar and cut into $1 \mathrm{~mm}$ cubes for handling. The cubes were fixed with $2.5 \%$ glutaraldehyde solution for 5 hours, rinsed four times with phosphate buffer, post-fixed with $1 \%$ osmium tetroxide for two hours, and again rinsed four times with phosphate buffer $(0.2 \mathrm{M}, \mathrm{pH}$ 7.4). Five cubes in total were dehydrated in a sequential series of ethanol solutions $(50,70,80,90$, $95,100,100 \%$ ), at room temperature, with 15 minutes at each step. After these dehydrated samples were solvated twice with propylene oxide for 30 minutes each, they were impregnated successively with mixtures $(1: 2$, 1:1 and 2:1) of Epon 812 epoxy resin and propylene oxide for 3 hours at each step. Finally, 100\% resin for polymerization was used at 35,45 and $60^{\circ} \mathrm{C}$ for 12,12 and 48 hours. Thin sections $70 \mathrm{~nm}$ in thickness were cut with a diamond knife on a ultramicrotome (Leica Ultracut UCT), mounted on carbon-coated copper specimen grids, and contrasted with uranyl acetate and lead citrate. The resulting thin sections were observed at an accelerating voltage of 100 and $120 \mathrm{kV}$.

The mineralogical properties of biomats were analyzed by X-ray powder diffractometer (XRD; Rigaku RINT2000) with $\mathrm{Cu} K \alpha$ generated at $40 \mathrm{kV}$ and $30 \mathrm{~mA}$

TABLE 1. ICP DATA ON THE CHEMICAL COMPOSITION OF HOT-SPRING WATER AT KAMUIWAKKA FALLS, HOKKAIDO, JAPAN

\begin{tabular}{ccccccccccc}
\hline $\mathrm{Si}$ & $\mathrm{Al}$ & $\mathrm{Na}$ & $\mathrm{Ca}$ & $\mathrm{K}$ & $\mathrm{Fe}$ & $\mathrm{Mn}$ & $\mathrm{Mg}$ & $\mathrm{S}$ & $\mathrm{B}$ & $\mathrm{P}$ \\
179.4 & 229.6 & 551.5 & 429.8 & 105.4 & 94.3 & 28.1 & 344.4 & 1681.7 & 7.7 & 0.2
\end{tabular}

These data were measured in December 1998. The compositions are reported in ppm. Gypsum appears upon evaporation of the hot-spring water. In addition, the $\mathrm{pH}$ controlling acid is both sulfuric and hydrochloric $\left(\mathrm{SO}_{4}{ }^{2-}: 4682 \mathrm{mg} / \mathrm{L}, \mathrm{Cl}^{-}: 1562 \mathrm{mg} / \mathrm{L}\right.$; measured by the Geological Survey of Japan, 1980). using the $2 \theta / \theta$ method and a scan speed $2 \%$ min. After air-drying, the powder samples were pipetted onto slide glasses to fit the diffractometer sample-holder. The structure of minerals on the cells was also established by transmission electron diffraction. The chemical composition was analyzed by energy-dispersion X-ray spectrometer (EDX; Philips PV9800) used with the SEM.

The chemical composition of hot-spring water from Kamuiwakka Falls was obtained by inductively coupled plasma (ICP) - emission spectrometry (SEIKO Instruments SPS7800) without pre-treatment (measured in December 1998). The water shows high concentrations of S (1681.7 ppm), and relatively high contents of $\mathrm{Na}$ (551.5 ppm), Ca (429.8 ppm), Mg (344.4 ppm) and Al (229.6 ppm). Concentrations of $\mathrm{Si}, \mathrm{K}$ and $\mathrm{Fe}$ are 179.4, 105.4, $94.3 \mathrm{ppm}$, respectively (Table 1 ). The $\mathrm{pH}$-controlling acid is both sulfuric and hydrochloric $\left(\mathrm{SO}_{4}{ }^{2-}\right.$ : $4682 \mathrm{mg} / \mathrm{L}, \mathrm{Cl}^{-}: 1562 \mathrm{mg} / \mathrm{L}$ ) (measured by Geological Survey of Japan, 1980). A spectrophotometer (Cecil CE3041) was also used to identify chlorophyll in microbes, and chlorophyll was then extracted in a mixture of acetone and distilled water (proportions, 4:1).

The silica encrustation was examined by Fourier transform-infrared absorbance spectroscopy (Jasco FT/ IR-610, MICRO-20). A small quantity of green biomats was suspended in distilled water. A drop of the suspension was mounted on a fluorite disk $\left(\mathrm{CaF}_{2}, 0.5\right.$ mm thick) for FT-IR analysis. After air-drying, cells were selected under the IR microscope. The masking aperture mechanically limited the measuring area to 30 $\times 30 \mu \mathrm{m}$. Cultivated cells without silica crusts (supplied by Prof. Enami, Science University of Tokyo) were also examined by the same method to compare with encrusted cells in green biomats.

\section{RESULTS}

\section{Observation of unicellular microbes in green biomats by optical microscopy}

Green biomats are mainly composed of colonies of green unicellular microbes that are spherical in shape (Fig. 1a). The size of cells ranges from 1.0 to $4.0 \mu \mathrm{m}$ (av. $2.0 \mu \mathrm{m}, N=100$ ) in diameter (Fig. 1b). Some of them show the endspore stage of formation (arrows in Fig. 1b). The colonies are partly transparent or pale brown in color, and angular in shape (Fig. 1c). The transparent or pale brown parts also show a matrix of colonies (arrows in Fig. 1d). Diatoms and bacteria were also found as minor components in green biomats.

The microbes fluoresce red when exposed to the light of 510-560 nm wavelength using a fluorescence microscope, indicating that the microbes contain chlorophyll $a$, which has absorption bands at 409 and $665 \mathrm{~nm}$ under a spectrophotometer. Point-staining within cells with DAPI led to a blue fluorescence under ultraviolet radiation (wavelength $365 \mathrm{~nm}$ ), suggesting that the spherical microbes are unicellular eukaryotes. On the basis of re- 

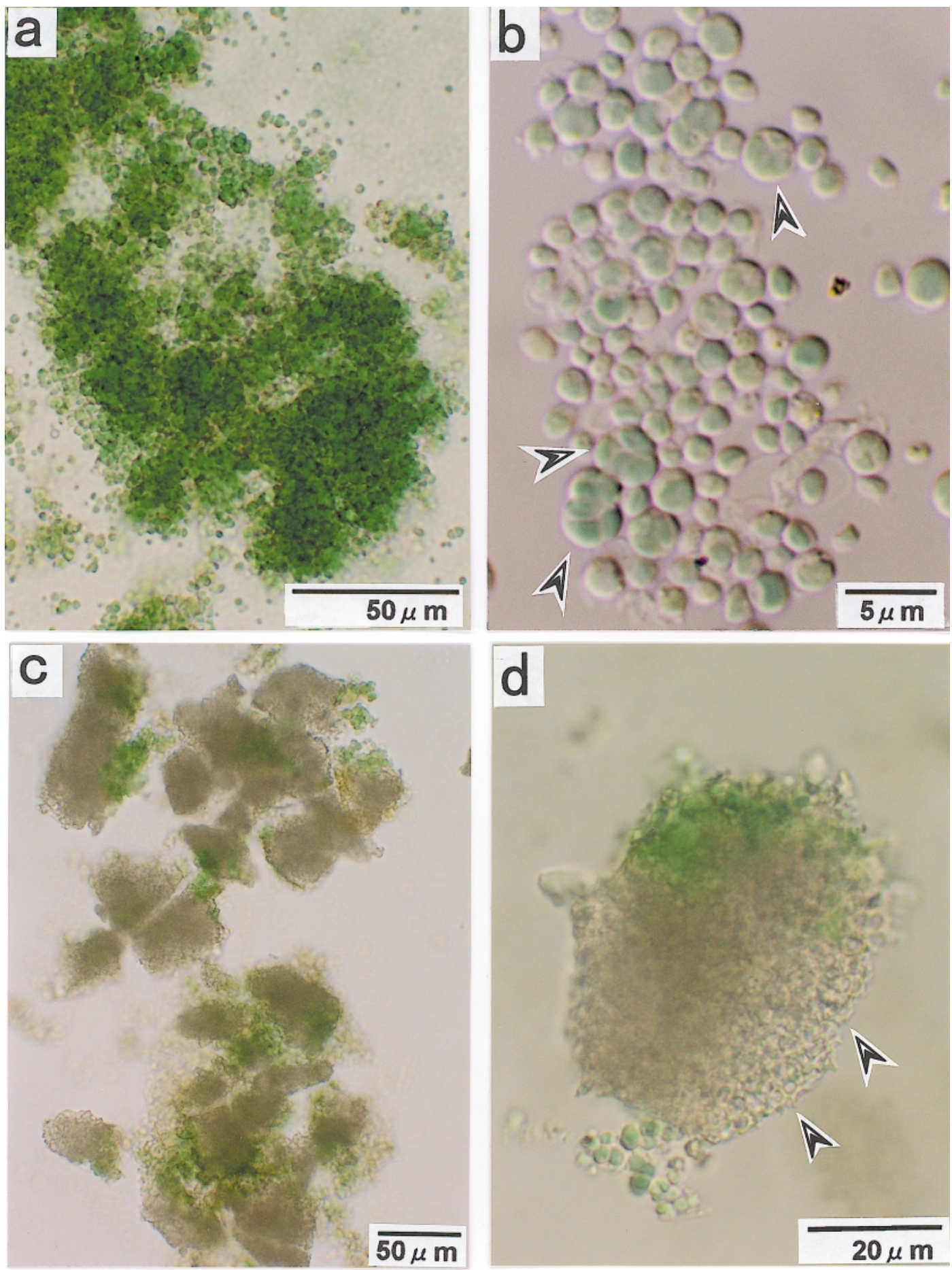

FIG. 1. Optical microscopic photographs of unicellular organisms in green biomats. (a) Colonies of unicellular green-colored and spherical microbes. (b) Cell sizes range between 1.0 and $4.0 \mu \mathrm{m}$ (av. $2.0 \mu \mathrm{m} ; N=100$ ) in diameter. Some show the endospore stage of formation (arrows in Fig.1b). (c) Partly transparent or pale brown colonies with an angular shape. (d) Transparent or pale brown parts showing matrices of colonies (arrows in Fig. 1d). 
gional characteristics, ecology, size, form, and structure of cell organelles, as described below, the microbes can be identified as the unicellular red alga Cyanidium caldarium (e.g., Hirose 1950, Fukuda 1958, Doemel \& Brock 1971, Ferris et al. 1986, Mann et al. 1992).

\section{$X R D$ analysis of green biomats}

An XRD analysis of the green biomats including microbes shown in Figures 1c and 1d reveals a broad peak corresponding to a $d$ of $4.0 \AA$ (Fig. 2). Electrondiffraction patterns agree with XRD result that the green biomats consist of amorphous or low-crystallinity material (a broad ring), as mentioned below in the section on TEM results. Its chemical composition was established by energy-dispersion X-ray-fluorescence spectroscopy (ED-XRF; JEOL JSX-3201). The biomats are high in $\mathrm{SiO}_{2}(95.7 \mathrm{wt} \%)$, with $\mathrm{SO}_{3}(3.4 \mathrm{wt} \%), \mathrm{K}_{2} \mathrm{O}(0.1$ wt $\%), \mathrm{CaO}(0.4 \mathrm{wt} \%)$ and $\mathrm{Fe}_{2} \mathrm{O}_{3}(0.3 \mathrm{wt} \%)$, together with traces of $\mathrm{TiO}_{2}, \mathrm{MnO}_{2}, \mathrm{NiO}$ and $\mathrm{CuO}$. These results indicate that the biomats consist of amorphous or lowcrystallinity silica.

\section{SEM observation of green biomats}

SEM observations of the surface of green biomats reveal that most unicellular microbes have a crust on their cell surface (Fig. 3a). Numerous granular particles attached to the cell walls form a coherent crust, with a few projections on the surface (Fig. 3b, projections: small arrows). EDX analysis showed that the crust is mainly composed of Si with a little $\mathrm{S}$ and $\mathrm{Cl}$ (Fig. 3c; analytical point: thick arrow in Fig. 3b).

Our SEM observation of vertically sectioned green biomats with white parts underneath revealed that the silica crust ranges from 0.1 to $1.0 \mu \mathrm{m}$ in thickness (Fig. 4a). On the lower part of the section from the surface to $1.0 \mathrm{~mm}$ in depth, the microbe body has been replaced by globular silica (Fig. 4b).

\section{TEM observation of unicellular microbes in green biomats}

A TEM investigation of unicellular microbes in green biomats revealed that a cell has a thin crust of silica (Fig. 5a). An electron-diffraction pattern shows that the crust is structurally amorphous; see inset (analytical point: small arrow in Fig 5a). The silica crust was stripped off from unicellular microbes by ultrasonic treatments (Fig. 5b). This cell showed a high densitycontrast, suggesting that the cell itself also is mineralized. An electron-diffraction pattern shows that the silica crust is of low crystallinity; see inset (a broad ring; analytical point: small arrow in Fig 5b).

A TEM examination of thin-sectioned unicellular microbes in green biomats revealed the relationships between silica crusts, cell walls, and cytoplasm. The double-layer silica crust consists of a layer of granular

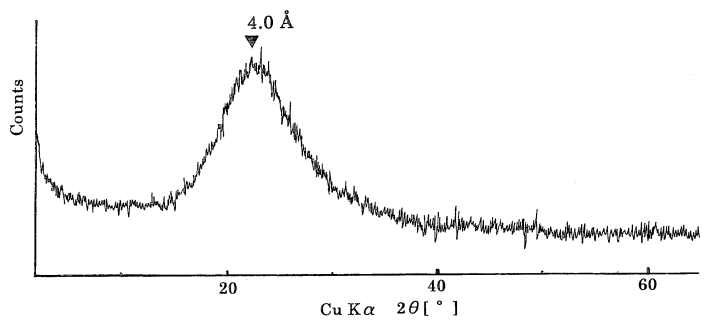

FIG. 2. X-ray powder-diffraction pattern of green biomats composed of unicellular microbes showing broad peak with a maximum at $4.0 \AA$ A, suggesting amorphous or low-crystallinity silica.

particles of uniform size (about $40 \mathrm{~nm}$ ) spaced at uniform intervals (Fig. 6a). A chloroplast (Ch) occupies the greater part of the cell. Starch granules (S) are present outside the chloroplast. Several granular particles (110 pieces) were found to be clustered within the chloroplast. Silica crust also forms during the endospore stage (Fig. 6b). Furthermore, a single layer of silica crust assimilates the outer wall of the cell (Fig. 6c). Cytoplasm is located far from the silica crusts. A double-layer silica crust forms on both outer and inner walls of cells, whereas granular particles of silica are not found on the surface of cytoplasm (Fig. 6d).

\section{IR spectra of unicellular microbes in green biomats}

An IR spectrum of cells with a silica crust shows bands at $3700-3100 \mathrm{~cm}^{-1}\left(\mathrm{O}-\mathrm{H}\right.$ stretch), $3288 \mathrm{~cm}^{-1}(\mathrm{~N}-$ $\mathrm{H}$ stretch), $2924 \mathrm{~cm}^{-1}$ (C-H stretch), $1648 \mathrm{~cm}^{-1}$ $\left(\mathrm{C}=\mathrm{O}\right.$ stretch), $1542 \mathrm{~cm}^{-1}$ (C-N-H combination) and $1078 \mathrm{~cm}^{-1}$ band (Si-O stretch) (Fig. 7a). On the other hand, an IR spectrum of cultivated cells without silica crusts shows bands at $3700-3100 \mathrm{~cm}^{-1}$ (O-H stretch), $3289 \mathrm{~cm}^{-1}$ (N-H stretch), $2925 \mathrm{~cm}^{-1}$ (C-H stretch), $1656 \mathrm{~cm}^{-1}(\mathrm{C}=\mathrm{O}$ stretch$)$ and $1543 \mathrm{~cm}^{-1}(\mathrm{C}-\mathrm{N}-\mathrm{H}$ combination) (Fig. 7b). In addition, the most likely explanation is that the $1150-1060 \mathrm{~cm}^{-1}$ band is derived from $\mathrm{C}-\mathrm{O}-\mathrm{C}$ stretch because the EDX analysis of shell-less (lab-cultivated) microbes do not show a signal for $\mathrm{Si}$. Both spectra indicate that the $\mathrm{N}-\mathrm{H}, \mathrm{C}=\mathrm{O}$ and $\mathrm{C}-\mathrm{N}-\mathrm{H}$ bands are derived from peptides in cells, whereas the $\mathrm{Si}-\mathrm{O}$ band shown in Figure $7 \mathrm{a}$ is derived from silica crusts.

\section{DISCUSSION}

\section{Silica biomineralization of unicellular microbes under acidic condition}

A schematic model for the formation of silica crust by $C$. caldarium under strongly acidic conditions has been developed (Fig. 8). The reason for a double-layer silica crust is that microbes observed in this study are 

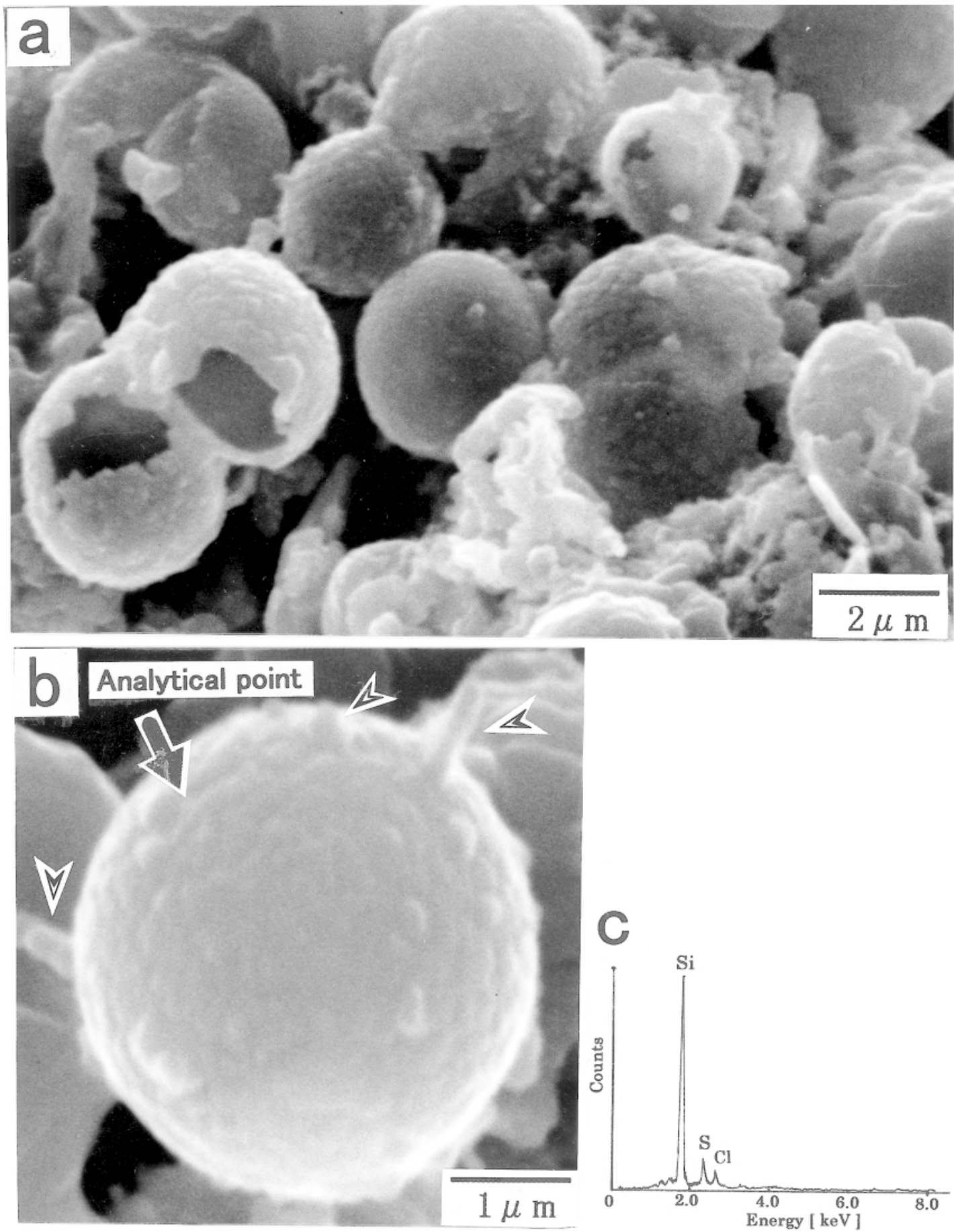

FIG. 3. SEM micrographs of unicellular microbes showing silica crusts on the cell walls. (a) Several unicellular microbes in a colony. (b) Micrograph of a crust with numerous granular particles and projections (small arrows). (c) EDX spectrum of the crust shows a strong peak of Si and weak peaks of S and $\mathrm{Cl}$. Analytical point: thick arrow in (b). 

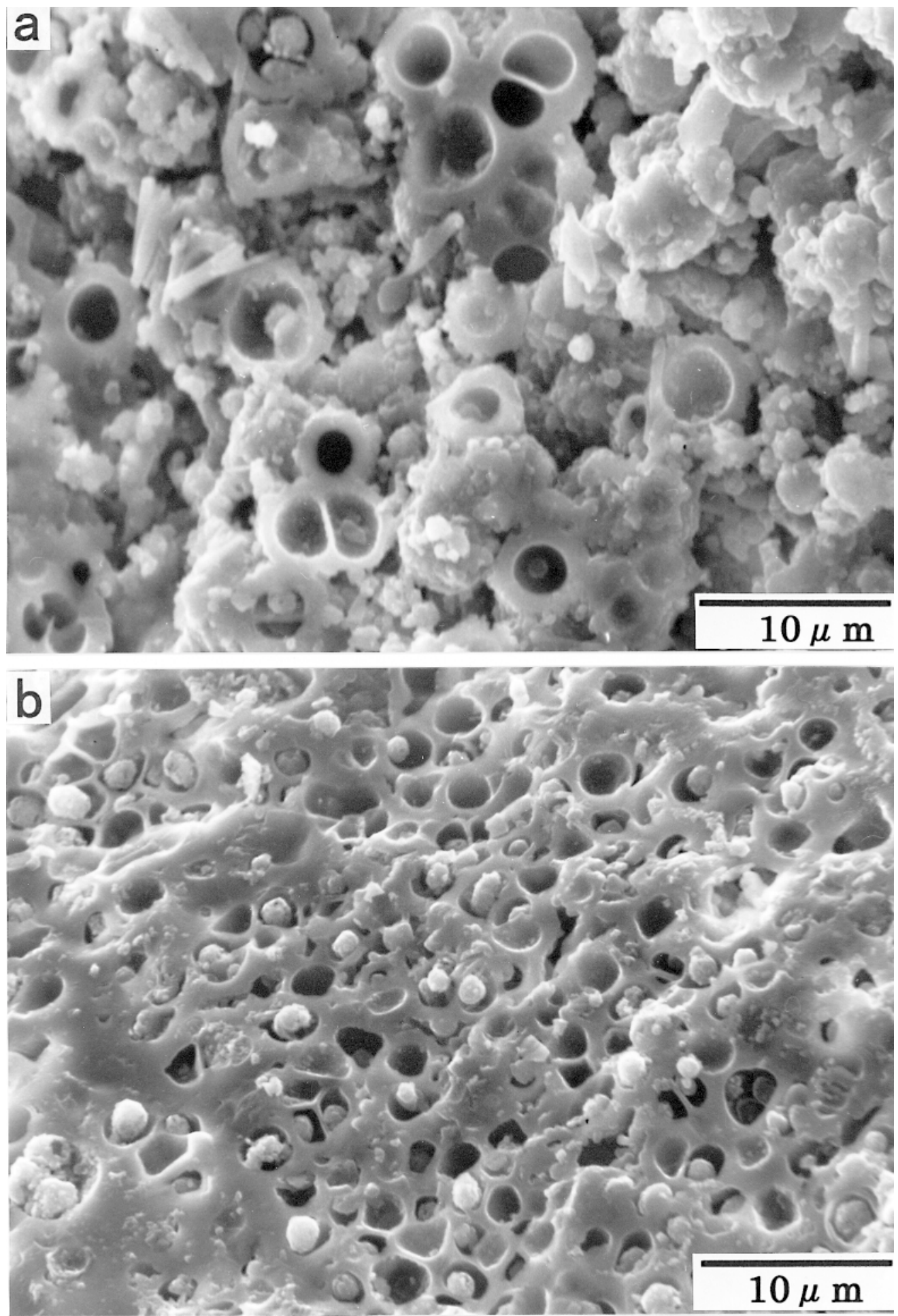

FIG. 4. SEM micrographs of vertical section of green biomats with white parts underneath. (a) An upper part of the section at a depth of $0.5 \mathrm{~mm}$ from surface. (b) A lower part of the section at a depth of $1.0 \mathrm{~mm}$ from surface. 

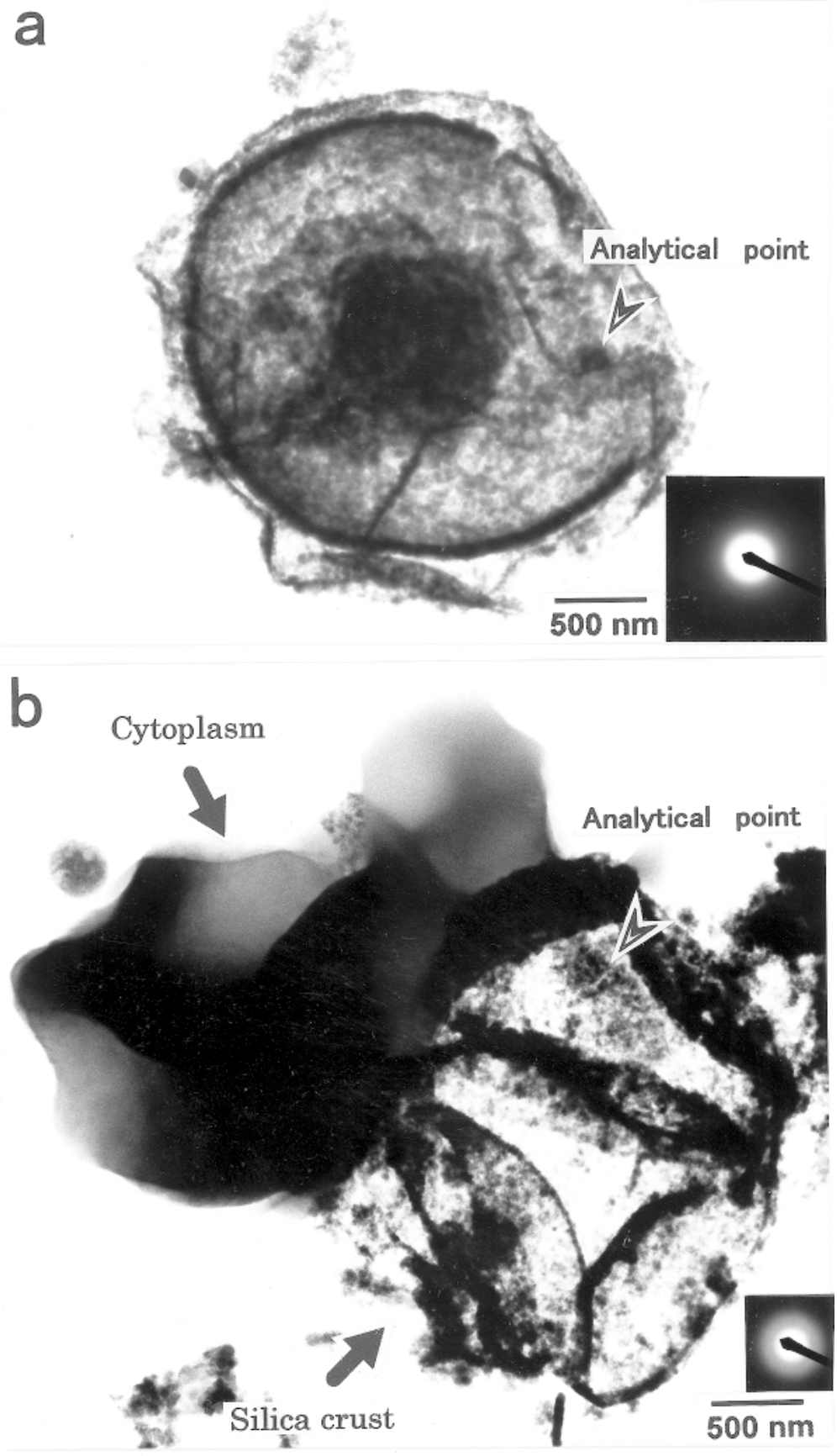

FIG. 5. TEM micrographs of unicellular microbes in green biomats. (a) A cell covered with silica crusts. Electron-diffraction pattern shows the structurally amorphous nature of the silica crust: inset (analytical point: small arrow in Fig. 6a). (b) Unicellular microbes showing a high density of population after stripping off the silica crust. Electrondiffraction pattern of silica crust shows evidence of its poor crystallinity: inset (analytical point: small arrow in Fig. 6b). 

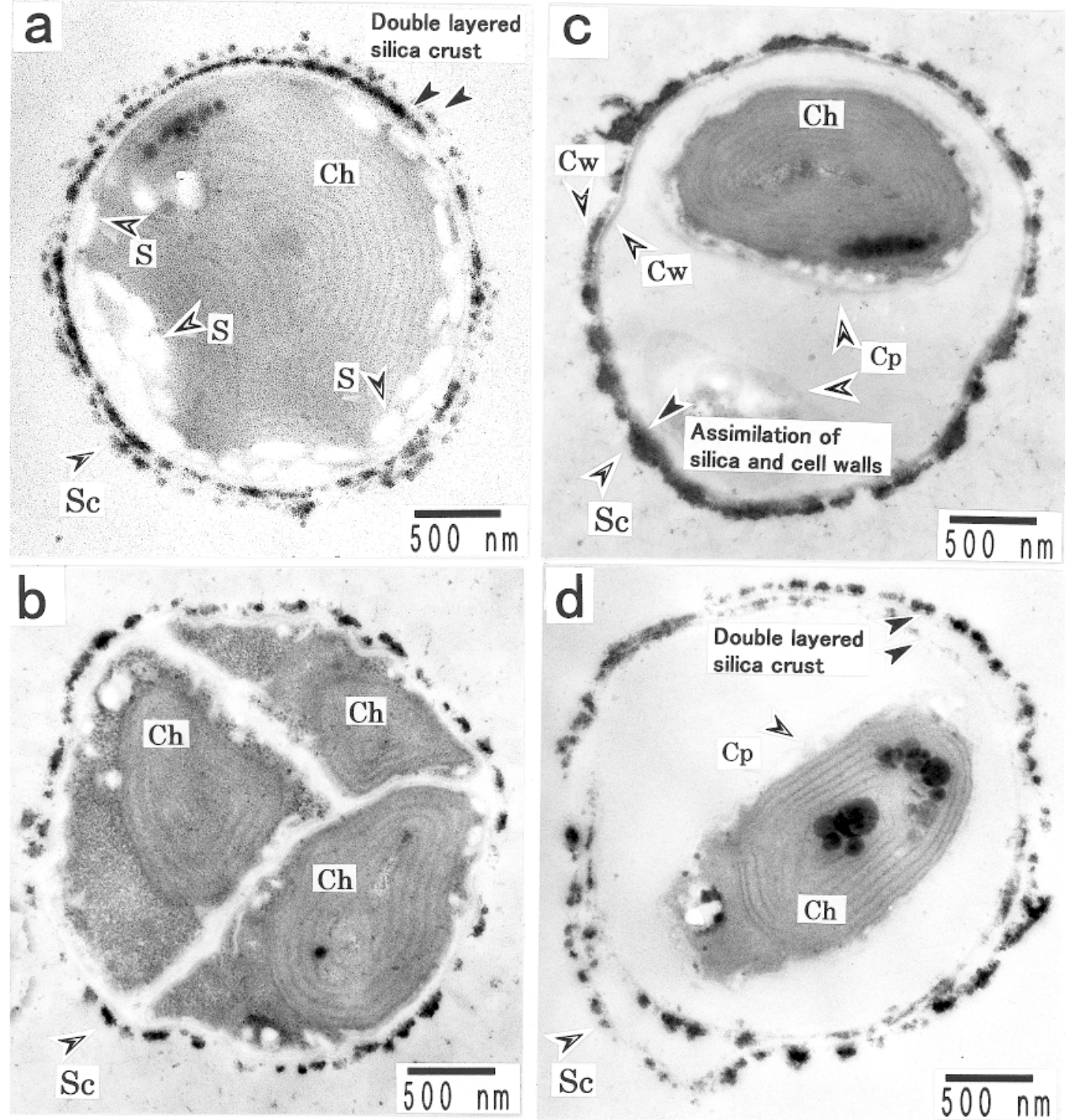

FIG. 6. TEM micrographs of thin-sectioned unicellular microbes in green biomats showing relationships between silica crusts, cell wall and cytoplasm. (a) Double-layer silica crust with granular spherules on the cell wall. (b) Silica crust at the stage of an endospore. (c) A single-layer silica crust assimilates the outer cell wall, maintaining a distance from cytoplasm. (d) A double-layer silica crust forms on both outer and inner walls of a cell. Granular particles of silica are not found on the surface of cytoplasm. Sc: silica crust, Ch: chloroplast, S: starch granules, Cp: cytoplasm.

the acidophilic and thermophilic red alga, C. caldarium, which have a double-layer cell wall (Nagashima \& Fukuda 1981).

The cell walls of microbes generally include, more or less, polysaccharides and proteins, and have an affin- ity for silica (e.g., Renaut et al. 1998). Mizutani et al. (1998) also reported that amines, notably polyamine, catalyze the polycondensation of silicic acid in water.

In general, microbes have the ability of regulating pH. For example, Vrieling et al. (1999) suggested that 

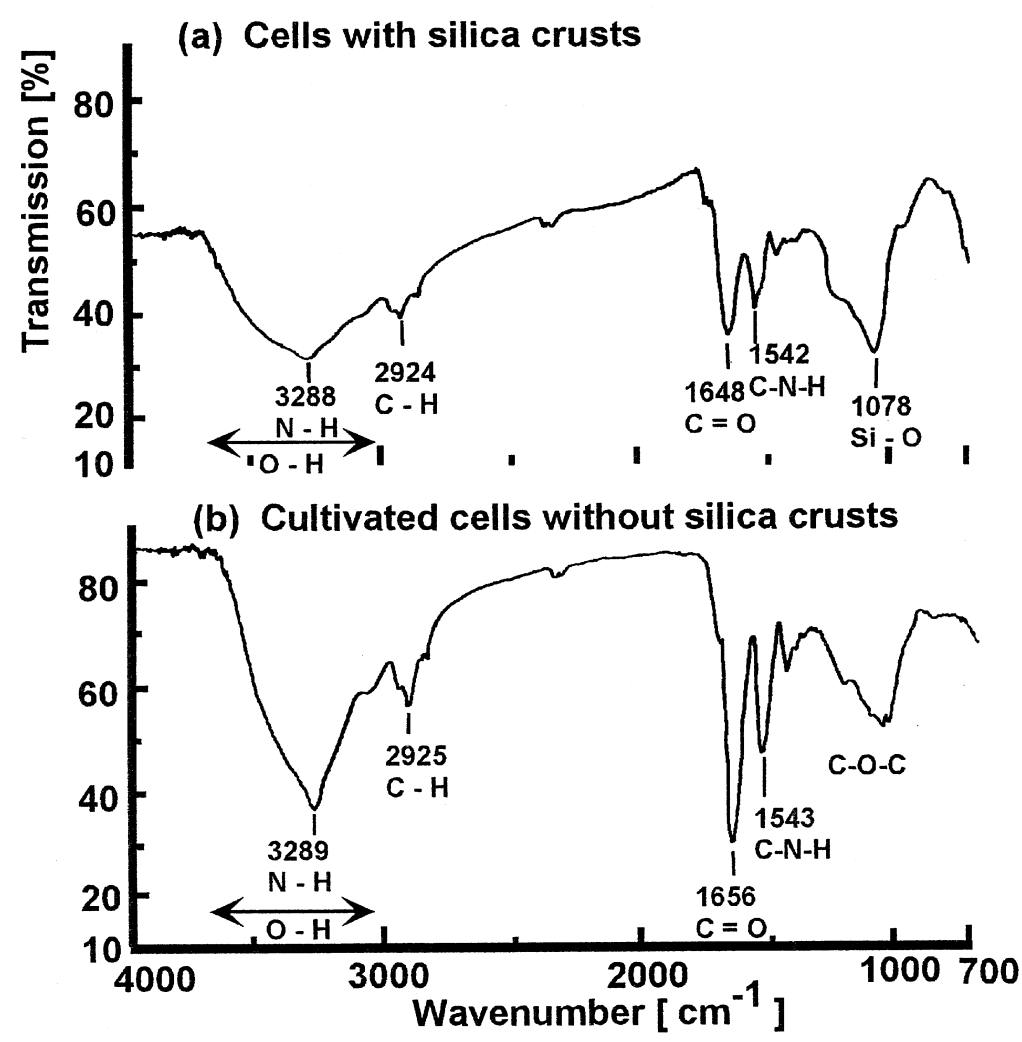

FIG. 7. IR spectra of unicellular microbes. (a) cells with silica crusts, and (b) cultivated cells without silica crusts. The $\mathrm{N}-\mathrm{H}, \mathrm{C}=\mathrm{O}$ and $\mathrm{C}-\mathrm{N}-\mathrm{H}$ bands are derived from peptides contained in cells. In (a), the $\mathrm{Si}-\mathrm{O}$ band $\left(1078 \mathrm{~cm}^{-1}\right)$ is derived from silica crusts.

the existence of a pH gradient between the silicon-deposition vesicle (SDV) and other organelles is important in the silicification of diatoms. Therefore, the formation of silica crusts could occur with microbes other than C. caldarium in this environment. We cannot compare the silicification of $C$. caldarium with that of other microbes, however, because other types are rarely found in this environment (e.g., $\mathrm{pH}<2$, sulfuric acid, high temperature, etc.). One must note that $C$. caldarium has a specific type of cell wall (Nagashima \& Fukuda 1981, Bailey \& Staehelin 1968) and a great ability to regulate $\mathrm{pH}$ to permit its tolerance to acid (Enami et al. 1986). Examples of specificity of the cell walls are that the protein is rich in the amino acids serine and threonine, and that the polysaccharide is rich in hemicellulose (Bailey \& Staehelin 1968). The great ability to regulate $\mathrm{pH}$ also causes a strong gradient in $\mathrm{pH}$ across the external walls of the cell with fluctuation in $\mathrm{pH}$.

It is necessary for $C$. caldarium to show tolerance not only to acid but also to silica in sites near the spouts of hot springs. The nature of proteins and polysaccha- rides in cell walls of microbes can determine the affinity for silica in various environments. Therefore, the cell walls of $C$. caldarium may also have the proper structure for the grade of silicification, or the potential for change. The double-layer silica crust seems to offer protection against silification of the cytoplasm (Figs. 6c, d).

Granular particles of a uniform size are placed in order at uniform intervals on the cell walls (Fig. 6a). Our findings suggest that the surface of the cell walls has both positive and negative sites for nucleation of colloidal silica and for polymerization of silicic acid. There are two hypotheses on determination of distributions of these sites on the surface of the cell wall. One possibility is to assume that the structure of cell wall depends on the environments where the ancestral cell lived. Another possibility is that living cells have the ability to change a positive site for silicification on the surface of the cell wall. The results of our TEM observations of ultra-thin sections suggest a distribution of positive and negative sites for silicification on the cell wall as follows (Fig. 9). When it is necessary for $C$. 
$-\int_{-1}^{1} \int_{1}^{-1}-$

Formation of silica crust
on unicellular microbes

- Case of Cyanidium caldarium -

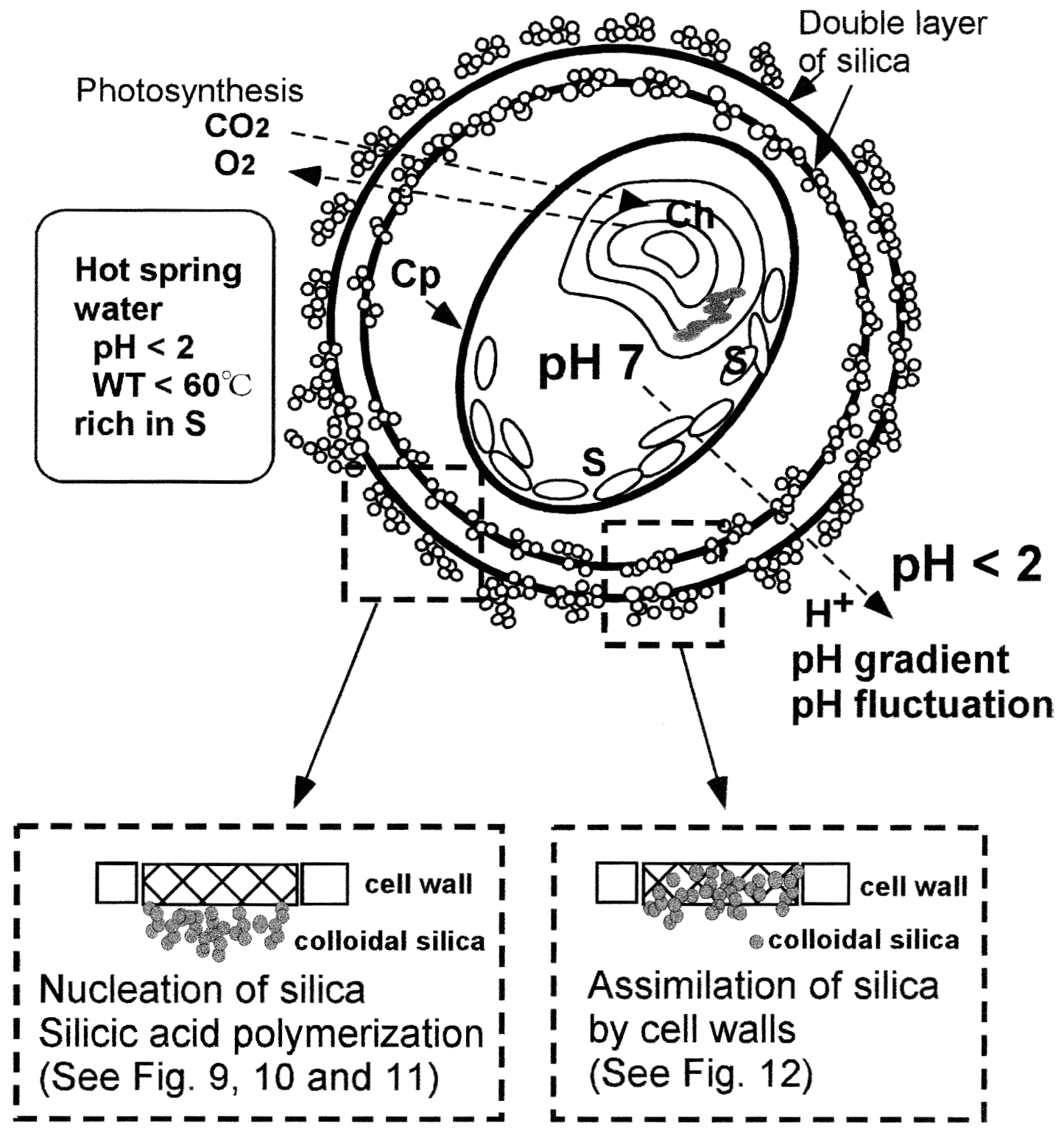

FIG. 8. A schematic model to explain the formation of a silica crust by Cyanidium caldarium under strongly acidic conditions. $\mathrm{Cw}$ : cell wall, $\mathrm{Cp}$ : cytoplasm, $\mathrm{Ch}$ : chloroplast, $\mathrm{S}$ : starch granules. 


\section{Cell walls for silicification}

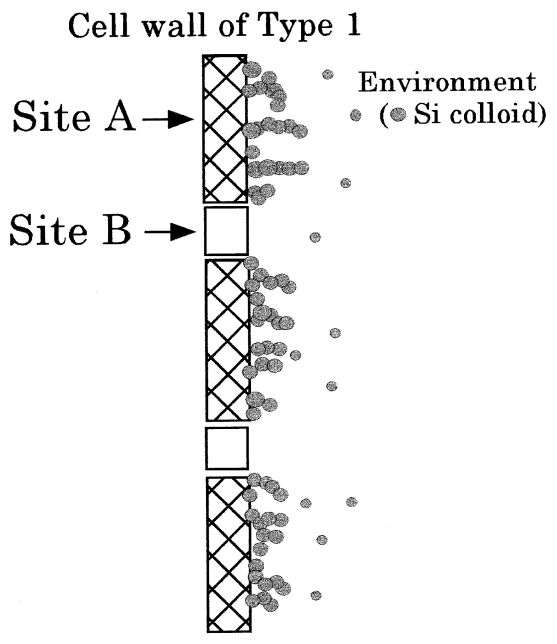

Cell wall of Type 2

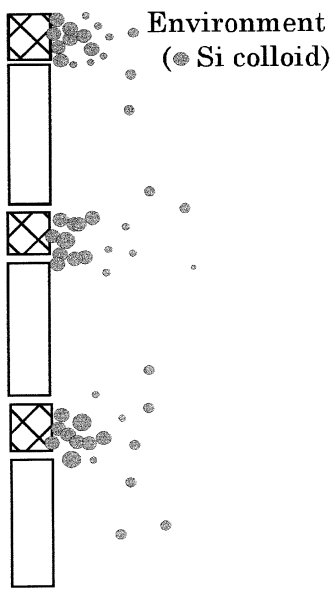

Surface on the cell wall of Type 1
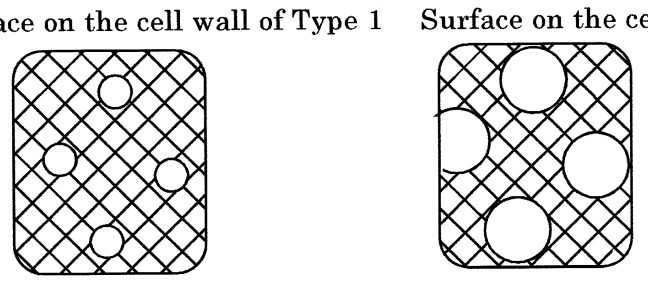

Site A

(Positive site for nucleation of silica and silicic acid polymerization)

Site B

(Negative site for nucleation of silica and silicic acid polymerization)

FIG. 9. A model for the distribution of positive and negative sites for silicification on the surface of the cell wall. When it is necessary for $C$. caldarium cell to precipitate silica, the surface of the cell wall will select the structure as Type 1 . In contrast, when it is not necessary to precipitate silica, the surface of cell wall will select the structure as Type 2 .

caldarium cells to precipitate silica, the surface of the cell wall will "select" the structure referred to as Type 1 (Fig. 9). In contrast, when it is not necessary to precipitate silica, the surface of the cell wall will "select" the structure referred to as Type 2 (Fig. 9).

Several positive sites for nucleation of silica on the cell surface are suggested as follows (Fig. 10). As mentioned above, the cell walls of $C$. caldarium are usually rich in protein and contain small amounts of polysaccharide. Therefore, at a positive site, a hydroxyl group, a peptide bond, amine and a carboxyl group on the surface of cell wall project outside the cell wall shown in Figure 10. They form a hydrogen bond with silicate ions. After that, silica combines with the positive sites by dehydration.

Polymerization of silica was found on the surface of cell wall in this study. A model is suggested for the polymerization of silica as follows (Fig. 11). The cell walls of $C$. caldarium are considered to work as a static barrier against proton $\left(\mathrm{H}^{+}\right)$influx into the interior of the cell, because the cell wall of $C$. caldarium can absorb a large amount of hydrogen ions $\left(\mathrm{H}^{+}\right)$(Imanaka \& Matsuzawa 1991). When a silicate ion attacks the surface of a cell wall (Fig. 11a), a silicate ion with high reactivity is generated (Fig. $11 \mathrm{~b}$ ); then, if other silicate ions attack the highly active silicate ion, polymerization of silica increases with dehydration (Fig. 11c). Water generated by dehydration has an important role in the tolerance of microbes to acids.

Our TEM observations of ultra-thin sections revealed an assimilation between silica and cell wall (Fig. 6c). Proteins and polysaccharides in the cell walls of $C$. caldarium play an important role in the assimilation. A mechanism to explain how silica combines inside hemi- 


\section{Hydroxyl group (proteins and polysaccharides (hemicellulose))}

proteins (serine, threonine, glycine, tyrosine)

hemicellulose (xylan, glucan, xyloglucan, mannan)

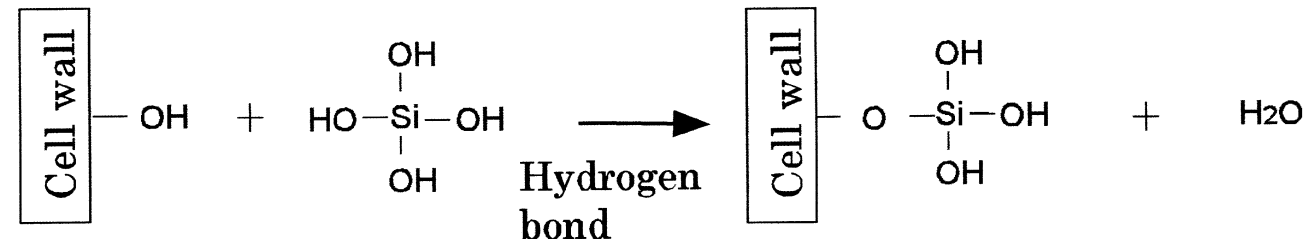

Peptide bond (proteins)

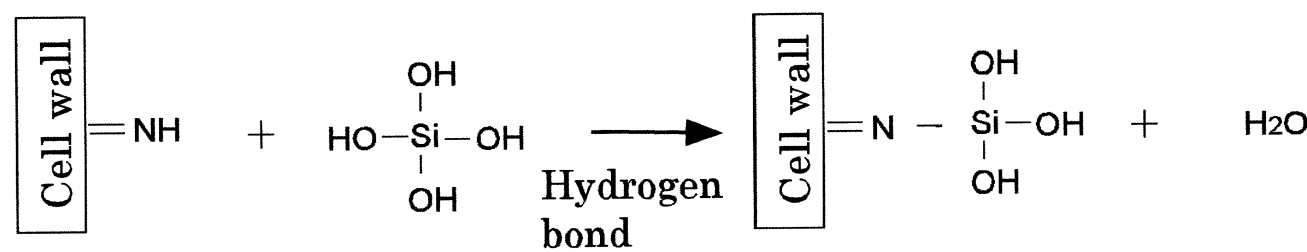

Amine

proteins (lysine)

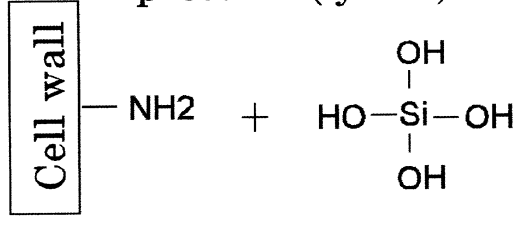

bond

\section{Carboxyl group}

proteins (glutamic acid, aspartic acid)

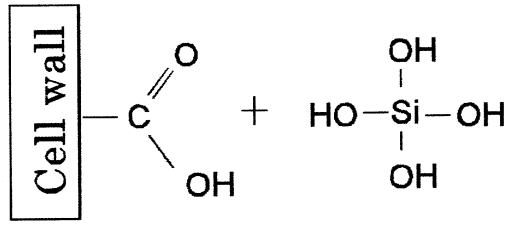
bond

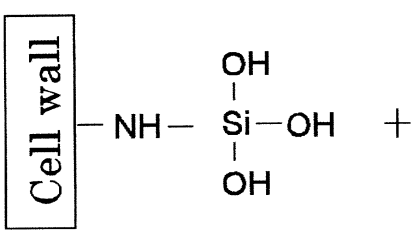

$\mathrm{H}_{2} \mathrm{O}$

FIG. 10. A model showing several positive sites for nucleation of silica on the cell surface. In the positive site, hydroxyl group, peptide bond, amine and carboxyl group on the surface of cell wall project outside the cell wall. They form a hydrogen bond with silicate ions. After that, silica combines with the positive sites by dehydration.

cellulose (e.g., mannan) is suggested in this study (Fig. 12). Mechanisms of assimilation between proteins and silica are not suggested, because the structure of proteins is very complicated. In the model of assimilation between mannan and silica, silicate ion combines inside mannan as five- or six-coordinated silicon, similar to the hypervalent silicon complexes suggested by Kinrade et al. (1999) (Fig. 12). Hydrogen ions and electrons are necessary for silicate ions to combine inside mannan by such a mechanism. As mentioned above, a large number of hydrogen ions $\left(\mathrm{H}^{+}\right)$exist at the surface of cell walls as a static barrier against proton $\left(\mathrm{H}^{+}\right)$influx into the interior of the cell. Electrons would also be supplied from some metabolic pathway of $C$. caldarium. Water 


\section{Polymerization of silica on the surface of cell wall}
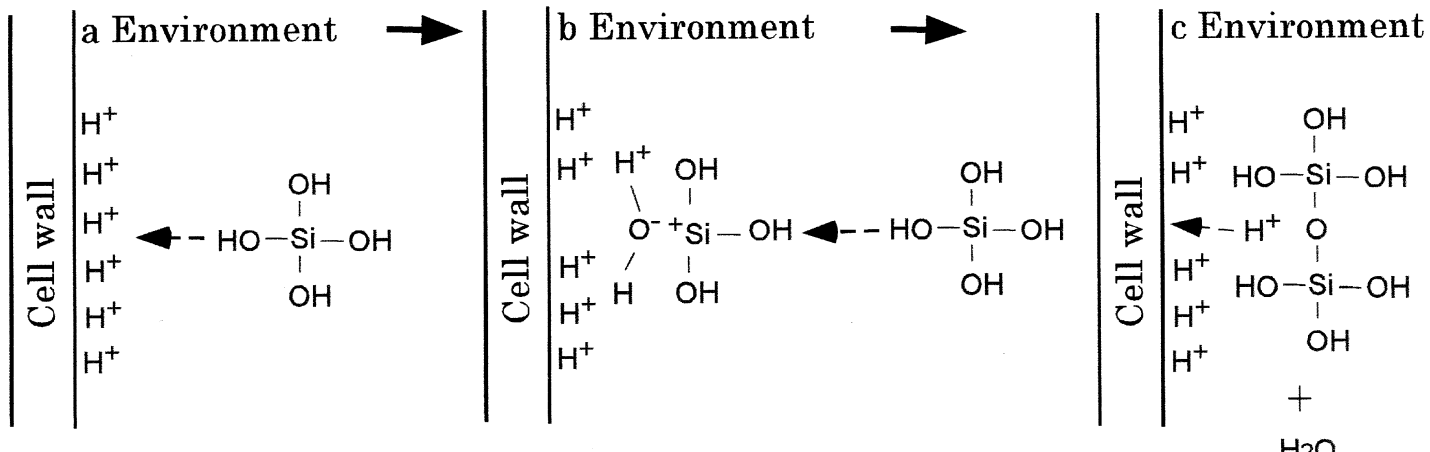

FIG. 11. A model to explain the polymerization of silica. The cell wall of $C$. caldarium can absorb a large amount of hydrogen ions $\left(\mathrm{H}^{+}\right)$. When a silicate ion attaches itself to the surface of the cell wall, a silicate ion with high reactivity is generated. Then, if other silicate ions attach themselves to the active silicate ion, the degree of polymerization of silica rises with dehydration. Water generated by dehydration plays an important role in the tolerance of microbes to acids.

generated by this mechanism has an important role in the tolerance of microbes to acids.

Investigations of silica biomineralization of unicellular organisms demonstrate that there are implications for the evolution of siliciferous microbes. Although a few projections on the surface of silica crusts (Fig. 3b) resemble actinopodia of siliciferous microbes such as radiolaria and heliozoida, these formations seem to be accidental.

Silica crusts containing dead cells remain in situ as white biomats (Fig. 4a). The interspaces between silica crusts are progressively filled with silica (Fig. 4b). The complexes of silica and microbes in green biomats support our hypotheses that such species play a significant role in the biological uptake and transport of silicon and in mineral diagenesis.

\section{ACKOWLEDGEMENTS}

The authors thank the Environment Agency for permission to collect specimens in the Shiretoko National Park, Opto Science, INC. for use of the spectroscopic analyzer and SEIKO Instruments, Inc. for use of the ICP emission spectrometer. The authors are also grateful to Dr. N. Gochi of the Shiretoko Museum for his help with field work, to Prof. I. Enami, Science Univ. of Tokyo, for giving them useful information on Cyanidium caldarium, to Dr. T. Kurihara of the High Technology Research Center, Kanazawa Medical University, for use of the ultramicrotome, and to Dr. M. Okuno of Kanazawa University, for use of the FT-IR spectroscope. The authors thank Prof. K. Kato, Shinshu University, and Drs. B. Roser and P. Murrow of Shimane University, for their helpful comments. The authors also thank Drs. I.R. Jonasson, an anonymous reviewer and R.F. Martin for their valuable suggestions concerning this paper.

\section{REFERENCES}

Akai, K., Kurokawa, K. \& Akai, J. (1995): Growing stromatolites at the Onikobe and Akakura hot-springs, Japan. Earth Science (Chikyu Kagaku) 49, 292-297 (in Japanese).

AsADA, R. \& TAZAKI, K. (1999): Biomineralization of silica under strong acidic condition. Proc. Int. Symp. Kanazawa, -Earth-Water-Humans-, Kanazawa Univ., 209-216.

$\&$ (2000): Biomineralization of silica associated with colonization of an unicellular alga, Cyanidium caldarium, in an acidic hot spring. J. Geol. Soc. Japan 106, 597-608.

BAiley, R.W. \& Staehelin, L.A. (1968): The chemical composition of isolated cell walls of Cyanidium caldarium. $J$. Gen. Microbiol. 54, 269-276.

Doemel, W.N. \& Brock, T.D. (1971): The physiological ecology of Cyanidium caldarium. J. Gen. Microbiol. 67, 1732.

EHRLICH, H.L. (1996): How microbes influence mineral growth and dissolution. Chem. Geol. 132, 5-9.

ENAmi, I., AKuTsu, H. \& KYogoku Y. (1986): Intracellular pH regulation an acido-philic unicellular alga, Cyanidium caldarium: ${ }^{31} \mathrm{P}-\mathrm{NMR}$ determination of intracellular $\mathrm{pH}$. Plant Cell Physiol. 27, 1351-1359.

FERrIs, F.G., BEVERIDGE, T.J. \& FyFe, W.S. (1986): Iron-silica crystallite nucleation by bacteria in a geothermal sediment. Nature 320, 609-611. 


\section{Hemicellulose (e.g. Mannan)}

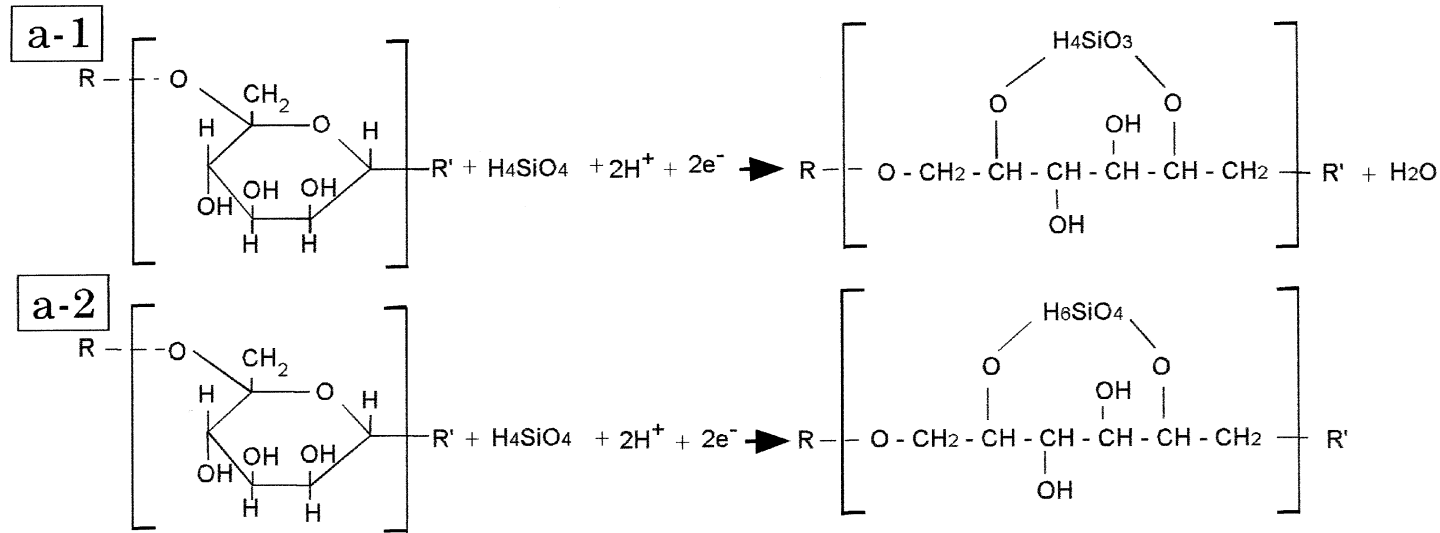

\section{b-1}

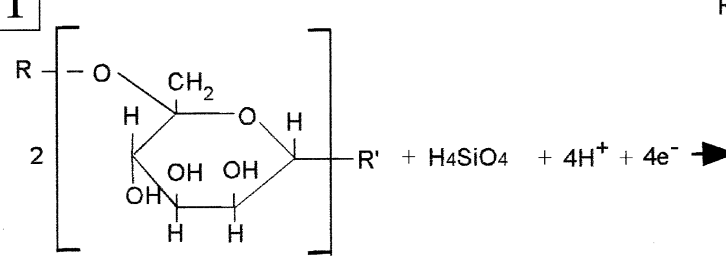

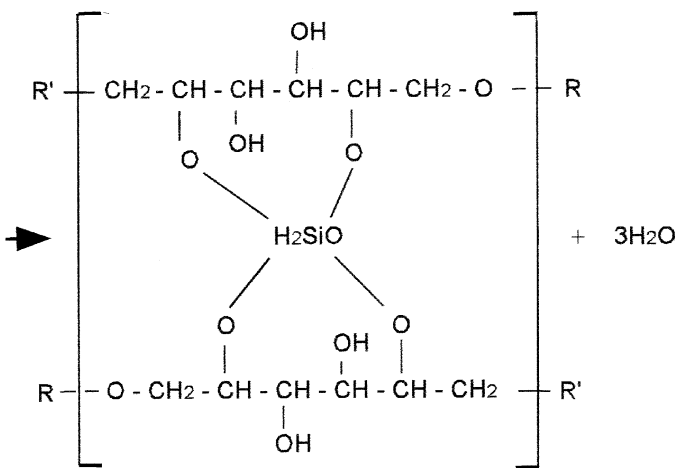

\section{$\mathrm{b}-2$}

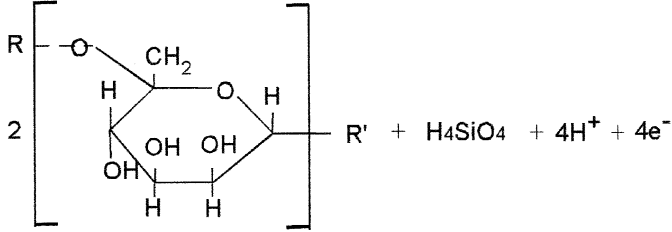

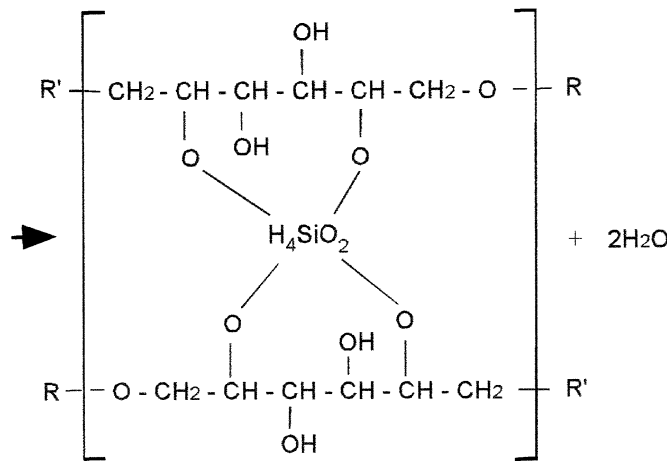

FIG. 12. A model to explain the combination involving silica and hemicellulose (e.g., mannan). In this model, silicate ions combine inside mannan as five- or six- coordinated silicon. Hydrogen ions and electrons are necessary for silicate ions to combine inside mannan. a-1. Five-coordinated silicon in a single chain of mannan. a-2. Six-coordinated silicon in a single chain of mannan. b-1. Five- coordinated silicon in double chain of mannan. b-2. Six-coordinated silicon in a double chain of mannan. 
FUKUDA, I. (1958): Physiological studies on a thermophilic blue green alga, Cyanidium caldarium Geitler. Bot. Mag. Tokyo 71, 79-86.

HARPER, H.E., JR. \& KNOLL, A.H. (1975): Silica, diatoms, and Cenozoic radiolarian evolution. Geology 3, 175-177.

Hirose, H. (1950): Studies on a thermal alga, Cyanidium caldarium. Bot. Mag Tokyo 63, 107-111.

IMANAKA, T. \& MatsuZawa, H. (1991): A Handbook of Extreme Environment. Oshima T. Science Forum Company, Tokyo, Japan (translation from Japanese).

KinRade, S.D., Del Nin, J.W., Schach, A.S., Sloan, T.A., Wilson, K.L. \& KNIGHT, C.T.G. (1999): Stable five- and six-coordinated silicate anions in aqueous solution. Science 285, 1542-1545.

Mann, H., Tazaki, K., Fyfe, W.S. \& KerRich, R. (1992): Microbial accumulation of iron and manganese in different aquatic environments: an electron optical study. In Biomineralization Processes (H.C.W. Skinner \& R.W. Fitzpatrick, eds.). Catena, Suppl. 21, 115-131.

Mizutani, T., Nagase, H., Fujiwara, N. \& Ogoshi, H. (1998): Silicic acid polymerization catalyzed by amines and polyamines. Bull. Chem. Soc. Japan 71, 2017-2022.

NAGASHIMA, H. \& FuKudA, I. (1981): Morphological properties of Cyanidium caldarium and related algae in Japan. Jap. J. Phycol. 29, 237-242.

NAZARov, B. (1973): Radiolaria from the Lowest Cambrian horizons of Batenev Ridge. In Biostratigraphy and Paleontology of the Lower Cambrian of Siberia and the Far East. Novosibirsk Nauka 49, 31-35 (in Russ.).

(1975): Radiolaria of the Lower - Middle Paleozoic of Kazakhstan. Tr. Geol. Inst. Akad. Nauk SSSR 275, 1-202 (in Russ.).

Renaut, R.W., Jones, B. \& Tiercelin, J.J. (1998): Rapid in situ silicification of microbes at Loburu hot springs, Lake Bogoria, Kenya Rift Valley. Sedimentology 45, 1083-1103.

Schultze-Lam, S., Ferris, F.G., Konhauser, K.O. \& Wiese, R.G. (1995): In situ silicification of an Icelandic hot spring microbial mat: implication for microfossil formation. Can. J. Earth Sci. 32, 2021-2026.

Shikaura, H., Tawara, K. \& TAZaKi, K. (1999): Microbes living in hot springs at the beach of Satsuma-Iwo Jima Island, southern Kyushu, Japan. Proc. Int. Symp., Kanazawa, -Earth-Water-Humans-, Kanazawa Univ., 197-208.
Tappan, H. \& Loeblich, A.R., JR. (1973): Evolution of the oceanic plankton. Earth-Sci. Rev. 9, 207-240.

TAZAKI, K. (1999a): Architecture of biomats reveals history of geo-, aqua-, and bio-systems. Episodes 22, 21-25.

(1999b): Microorganisms design the Earth history. Proc. Int. Symp., Kanazawa, -Earth-Water-Humans-, Kanazawa Univ., 187-196.

Aoki, A., Asada, R., Kishigami, Y., Matsumoto, K., Ohno, M., Sakurayama, K., Shikaura, H., Tawara, K., Ueshima, M., Watanabe, H. \& Yamamura, T. (1998): A new world in the science of biomineralization. In Environmental Biomineralization in Microbial Mats in Japan (K. Tazaki, ed.). Sci. Rep. Kanazawa Univ. 42, 65.

\& IsHIDA, H. (1996): Bacteria as nucleation sites for authigenic minerals. J. Geol. Soc. Japan 102, 866-878.

Matsumoto, K., Akai, J., Aoki, A., Asada, R., Kato, H., Ohno, M., Shikaura, H., Tawara, K., Ueshima, M., Watanabe, H. \& Yamamoto, H. (1997): Microbial mats in Japan. In Microbial Biomineralization (K. Tazaki, ed.). Kanazawa Univ., Kanazawa, Japan (p. 91).

Sato, T., Tawara, K. \& Yamamura, T. (1999): Biomineralization in hydrothermal systems. Gekkan Kaiyo 19, 211-216 (translation from Japanese).

Yamamura, T., Nagai, H. \& Koiwasaki, K. (1996): Banded architecture of bacterial control. Gekkan Chikyu 18, 9-16 (translation from Japanese).

Ullman, W.J., Kirchman, D.L., Welch, S.A. \& VandeVIVERE, P. (1996): Laboratory evidence for microbially mediated silicate mineral dissolution in nature. Chem. Geol. 132, 11-17.

VRIELING, E.G., GiesKes, W.W.C. \& BeELEN, T.P.M. (1999): Silicon deposition in diatoms: control by the $\mathrm{pH}$ inside the silicon deposition vesicle. J. Phycol. 35, 548-559.

Walter, M.R., BAuld, J. \& Brock, T.D. (1972): Siliceous algal and bacterial stromatolites in hot spring and geyser effluents of Yellowstone National Park. Science 78, 402405 .

Yamamura, T., Tawara, K., Tazaki, K., Chiba, H. \& IsHIBASHI, J. (1997): Needle-like minerals at Iheya Ridge. J. Mineral. Soc. Japan 26, 113-116.

Received October 22, 2000, revised manuscript accepted February 3, 2001. 